International Journal of Advanced Biological and Biomedical Research Available online at http:www.ijabbr.com

Volume 8, Issue 3 (2020) pp. 225-235

DOI: 10.33945/SAMI/IJABBR.2020.3.1

Original Article

\title{
Determine of Isolation Distances for Seed Potato Production in Ardabil Region
} Hossein Karbalaei Khiavi*, Davoud Hassanpanah

\author{
Plant Protection Research Department, Ardabil Agricultural and Natural Resources \\ Research and Education Centre, AREEO, Ardabil, Iran \\ *Corresponding Author E-mail: $\underline{\text { Hossein.Karbalaei@yahoo.com }}$
}

Received: 3 October 2019, Revised: 06 November 2019, Accepted: 4 December 2019

\begin{abstract}
This study was performed to determine the distance of isolation for the seed potato production from ware potato in three regions of Ardabil, Namin and Nir. The experiment was carried out in a randomized complete block design (RCBD) with five distances (100, 200, 300, 400 and 500 meters from ware potato) and three replications with Super Elite (SE) class of Agria potato cultivar from ware potato as the source of infection studied by ELISA during 2014 and 2015. According to standard of Seed and Plant Certification and Registration Institute (SPCRI), as many as 200 leaves and 200 tubers samples of each distance were collected and their virus infection was done by ELISA assay. Analysis of variance tuber yield showed that were significant differences between regions, years and distances of isolation. In terms of tuber yield, between distances 500, 400 and 300 meters, there was no significant difference and they were in one group. By reducing isolation distance from 500 meters to 100 meters from host of viral diseases vectors (edible potato of Agria cultivar) tuber yield reduced from $44.328 \mathrm{t} / \mathrm{ha}$ to $39.828 \mathrm{t} / \mathrm{ha}$ (about $4.5 \mathrm{t} / \mathrm{ha}$, or 10.15 percent). Average infection of Rhizoctonia fungal diseases of tuber in isolation distances and three regions were about 5 percent. In three regions and five isolation distances, tubers were without infection of vascular rot fungus diseases, without infection of bacterial diseases of blackleg and brown rot and without infection of potato moth pest. In each three regions, the PVY virus was in distances 100, 200 and 300 meters from the host. Insects of collected from yellow pan were 1.1\% green peach aphid, $1.78 \%$ thrips, $32.54 \%$ green cicada, $57.99 \%$ brown cicada, $1.18 \%$ hawk moth of potato and $5.41 \%$ other insects. To determine the exact isolation distance in different regions of potato cultivation in Ardabil province, additional projects, provided in the suggestions, need to be implemented.
\end{abstract}

Key words: Isolation distanc, Seed potato, Vectors, PVY

\section{Introduction}

The cultivated potato (Solanum tuberosum L.) is one of the world's most important foods and vegetable crops, rating fourth in production. It contains $78 \%$ water, $18 \%$ starch, $2 \%$ 
protein, $1 \%$ vitamins and several trace elements. It is the world's leading crop and grown in approximately 140 countries (Haase, 2008; Bhutta, 2008).

Considering moderate and suitable air condition, Ardebil province with a cultivated area of about 21,000 hectares and production of more than 800,000 tons of potatoes, is one of the favorite areas for cultivation of this crop (Hassanpanah, 2013). Isolation interval is important in potato seed production due to the importance of vectors in the transmission of viral and phytoplasma diseases. Determination of standards for production, reproduction and certification of seed potatoes should be done according to the conditions of the production area and its capabilities. In reproducing and producing seed tubers from certified seed, soil and preparation farm, soil health, crop health, water management, field health, seed tuber health, alternation Agronomic and observation of isolation distance were noted. Standards defined for potato mini-tuber production in India include mini-tuber weight of at least $1 \mathrm{~g}$, germination power of $90 \%$, purity of $99 \%$ and viral diseases $0.01 \%$ (Bostan et al., 2006). In India, they also consider isolating the minimum required distance between commercial potato fields and five-meter seed production. Other standards for seed production in India include high altitude seed production due to low contamination with aphids and other carriers during the potato growing season (Anonymous, 2005).

Commercial and seed potato production are constrained by several viral diseases that reduce yields and lower tuber quality (Ragsdale et al., 2001). Viral diseases are one of the most important inhibitors and contaminants of potatoes due to the coincidence of potato growth with the life span of viruses carrying aphids.

Potato viral diseases were first seen in Europe, but by 20th century their cause was unknown. To date, more than 35 different viruses have been reported from potatoes (Salazar, 1996). Some of the viruses are dependent on potato survival and spread and are of greater economic damage and importance. Hence, much research has been done on their identification, transmission and control worldwide (Mattews, 1991; Salazar, 1996; Buchen Osmond, 2002).

Potato virus damage varies from 10 to $90 \%$, depending on virus type, potato cultivar and environmental conditions; since potatoes are vegetatively propagated, this creates exclusive opportunities for pathogens to establish and spread several diseases (Khurana, 2004). Among the plant pathogens, more than 37 viruses are reported to infect potato crops. Potato leaf roll virus is one of the most important potato viruses in the world. Potato leaf roll virus (PLRV) can reduce tuber yield and quality in potato (Mondal et al., 2017). Potato virus Y (PVY) is the potato virus with the highest economic impact on seed potato production worldwide (Rolot, 2005; Valkonen, 2007). Depending on the breed, the damage is $10-70 \%$ in seasonal infections and up to $80 \%$ in primary infections (De Boks, 1987). Potato Virus X (PVX) and PLRV are considered more important due to major role they play in crop losses (Lung'aho et al., 2007; Olubayo et al., 2010).

Potato virus S (PVS) is a major plant pathogen that causes considerable losses in global potato production (Duan et al., 2018). The A potato virus was first introduced in 1932 (Murphy and Mckay, 1932). In Iran, only the distribution of specific potato viruses in some provinces has been studied, including PLRV, PVS and PVX viruses in Khorasan province (Beykzadeh et al., 2001), PLRV, PVA, PVY, PVS, AMV, PVM and TSWV viruses in Firoozkooh region, PLRV, PVA, PVY, PVS, AMV, PVM and TSWV viruses in Damavand region and PLRV, PVY, PVM, PVS, PVX and PVA viruses in Firoozkouh, Karaj and Tajarak station of Hamadan (Pajouhandeh et al., 2000). Ardebil's 95,000-hectare plain in terms of geographical location, 
elevation of $1400 \mathrm{~m}$ above sea level, enclosure by natural insulators, windsurfing (usually wind speeds of $7 \mathrm{~m} / \mathrm{s}$ at $10 \mathrm{~m}$ ) and activity limitations Viral vector carriers is one of the most important centers of potato production in Iran. Since there is no report on the existence and spread of potato viruses in Ardabil, the aim of this project is determination of the most suitable isolation distance for seed potato production in areas such as Ardabil, Namin and Nir, investigation of tuber yield at the studied isolation distances studied in each region and determination of vectors and viral diseases.

\section{Experimental}

\section{Materials and methods}

This study was conducted in three regions of Ardabil province (Ardabil, Namin and Nair) with the main host plant of potato viral vectors based on a randomized complete block design with five intervals (100, 200, 300, 400 and 500 meters) of edible potato (Agria cultivar) and three replicates from seed of superalite during 2014 and 2015.

Each plot consisted of 10 stacks of 20 meters with a distance of $75 \mathrm{~cm}$ and two plants with a distance of $25 \mathrm{~cm}$. Ammonium phosphate fertilizer at $150 \mathrm{~kg}$ twice $(50 \%$ at planting time and $50 \%$ at tuber formation), urea at $300 \mathrm{~kg}$ at three times $(25 \%$ at planting time, $50 \%$ at emergence and $25 \%$ immediately after tuber formed) and potassium sulfate fertilizer (100 kg) were applied on the basis of soil test. According to the guidelines of the Institute for Seed and Certification Research, 14 days before planting, 200 mid-stem leaf and 200 tuber samples were randomly prepared from each treatment and viral diseases of PVX, PVS, PVM, PVA, PVY and PLRV were evaluated by Double Antibody Sandwich-Enzyme Linked Immunosorbent Assay (DAS-ELISA) (Nasir et al., 2012; Anonymous, 2015). Bacterial and fungal diseases (superficial and vascular) were evaluated and compared with Tables 1-3. For the detection and identification of carriers of viral diseases during the growing season, light yellow pan with $15 \times 30 \mathrm{~cm}$ area with water content and $0.002 \%$ detergent was used. Analysis of variance of data was done and mean comparison was run based on LSD test using SAS 9.1 statistical software.

Table 1. Standard maximum tolerable pollution percentage in field and laboratory in pre basic class (S)

\begin{tabular}{cccc}
\hline & \multicolumn{3}{c}{ Seed class S } \\
Disease contamination (\%) & Primary & Final & Lab \\
\hline Symptoms of leaf roll virus & 1 & 0 & 0 \\
Mosaic, Pisk Symptoms and Symptoms of & 1 & 0 & 0 \\
PVY Symptoms & & & \\
Symptoms of Phyto Plasma & 1 & 0 & 0 \\
Rhizoctonia & 0 & 0 & 0 \\
Fungal diseases $\quad$ Vascular fungi & 0 & 0 & 0 \\
$\quad$ Black leg & 0 & 0 & 0 \\
Bacterial diseases $\quad$ Brown rot & 0 & 0 & 0 \\
Willow pest & 0 & 0 & 0 \\
Non green areas & 0 & 2 & 0 \\
Mixing cultivar & 0 & 0 & 0 \\
\hline
\end{tabular}

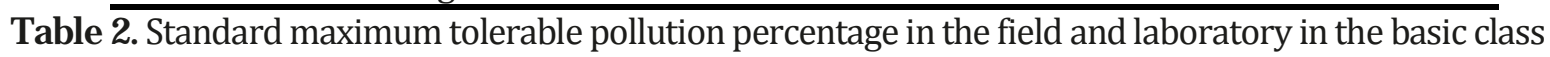
(SE and E) 


\begin{tabular}{|c|c|c|c|c|c|c|c|}
\hline \multirow{2}{*}{\multicolumn{2}{|c|}{$\begin{array}{l}\text { Disease Infection } \\
\text { (Percentage) }\end{array}$}} & \multicolumn{3}{|c|}{ Class SE } & \multicolumn{3}{|c|}{ Class E } \\
\hline & & Primary & $\begin{array}{l}\text { Final } \\
\text { Farm }\end{array}$ & Laboratory & Primary & $\begin{array}{l}\text { Final } \\
\text { Farm }\end{array}$ & Laboratory \\
\hline \multicolumn{2}{|c|}{ Symptoms of leaf roll virus } & 1 & 0.5 & 0.5 & 2 & 1 & 1 \\
\hline \multirow{2}{*}{\multicolumn{2}{|c|}{ Mosaic, Pisky Symptoms and }} & 1 & 0.5 & 1 & 2 & 1 & 2 \\
\hline & & & & & & & \\
\hline \multicolumn{2}{|c|}{ Other Viral Symptoms } & 1 & 0.5 & 0 & 2 & 1 & 0 \\
\hline \multicolumn{2}{|c|}{ Symptoms of Phyto Plasma } & 1 & 0.5 & 0 & 2 & 1 & 0 \\
\hline \multirow{2}{*}{$\begin{array}{c}\text { Fungal } \\
\text { diseases }\end{array}$} & Rhizoctonia & 0 & 0 & 0 & 0 & 0 & 0 \\
\hline & Vascular fungi & 2 & 0 & 0 & 3 & 0 & 0 \\
\hline \multirow{2}{*}{$\begin{array}{l}\text { Bacterial } \\
\text { diseases }\end{array}$} & Black Leg & 0.5 & 0 & 0 & 1 & 0 & 0 \\
\hline & Brown rot & 0 & 0 & 0 & 0 & 0 & 0 \\
\hline \multicolumn{2}{|c|}{ Willow pest } & 0 & 0 & 0 & 0 & 0 & 0 \\
\hline \multicolumn{2}{|c|}{ Non green Areas } & 0 & 4 & 0 & 0 & 5 & 0 \\
\hline \multicolumn{2}{|c|}{ Mixing cultivar } & 0 & 0 & 0 & 0.5 & 0 & 0 \\
\hline
\end{tabular}

Table 3. Standard maximum tolerable pollution percentage in the field and laboratory in the certified class $(\mathrm{A}, \mathrm{B}$ and $\mathrm{C})$

\begin{tabular}{|c|c|c|c|c|c|c|c|}
\hline \multirow{2}{*}{\multicolumn{2}{|c|}{ Disease Infection (Percentage) }} & \multicolumn{2}{|c|}{$\begin{array}{l}\text { Class A } \\
\text { Farm }\end{array}$} & \multicolumn{2}{|c|}{$\begin{array}{l}\text { Class B } \\
\text { Farm }\end{array}$} & \multicolumn{2}{|c|}{$\begin{array}{l}\text { Class C } \\
\text { Farm }\end{array}$} \\
\hline & & Primary & Final & Primary & Final & Primary & Final \\
\hline \multicolumn{2}{|c|}{ Symptoms of leaf roll virus } & 4 & 2 & 6 & 4 & 8 & 5 \\
\hline \multirow{2}{*}{\multicolumn{2}{|c|}{$\begin{array}{l}\text { Mosaic, Pisk Symptoms and } \\
\text { Symptoms of PVY Symptoms }\end{array}$}} & 4 & 2 & 6 & 4 & 8 & 5 \\
\hline & & 8 & 4 & 10 & 5 & 14 & V \\
\hline \multicolumn{2}{|c|}{ Symptoms of leaf roll virus } & 3 & 1.5 & 4 & 2 & 5 & 3 \\
\hline \multirow[b]{2}{*}{ Fungal diseases } & Rhizoctonia & 0 & 5 & 0 & 5 & 0 & 5 \\
\hline & Vascular fungi & 4 & 2 & 5 & 3 & 5 & 3 \\
\hline \multirow[b]{2}{*}{ Bacterial diseases } & Black leg & 3 & 2 & 4 & 3 & 5 & 4 \\
\hline & Brown rot & 0.5 & 0 & 0.5 & 0 & 1 & 0.5 \\
\hline \multicolumn{2}{|c|}{ Willow pest } & 0 & 0 & 0 & 0 & 0 & 0 \\
\hline \multicolumn{2}{|c|}{ Non green areas } & 0 & 5 & 0 & 5 & 0 & 5 \\
\hline \multicolumn{2}{|c|}{ Mixing cultivar } & 1 & 0.5 & 2 & 1 & 3 & 2 \\
\hline
\end{tabular}

\section{ELISA test steps (Nasir et al., 2012) (Anonymous, 2015)}

Agdia's ready-made kits were used for this test.

1. Providing wash buffer PBST Phosphate Buffer Saline = PBS-T (NaCl, KH2PO4, KCl, NaN3, Tween 20): To prepare the PBST wash buffer, the volume was dissolved in $1000 \mathrm{~mL}$ volume after dissolving the following substances in distilled water.

$$
\begin{array}{cc}
\text { Sodium chloride } & 8.0 \mathrm{~g} \\
\text { Sodium phosphate, dibasic (anhydrous) } & 1.15 \mathrm{~g} \\
\text { Potassium phosphate, monobasic (anhydrous) } & 0.2 \mathrm{~g}
\end{array}
$$




$\begin{array}{cc}\text { Potassium chloride } & 0.2 \mathrm{~g} \\ \text { Tween-20 } & 0.5 \mathrm{~g} \\ \mathrm{pH} & 7.4\end{array}$

$50 \mathrm{~mL}$ of PBST wash buffer prepared with $950 \mathrm{~mL}$ of distilled water was diluted.

This buffer was kept at room temperature when used and kept at $4{ }^{\circ} \mathrm{C}$ when not in use.

2. Providing general extract buffer (GEB): Method 1: to $16.5 \mathrm{~g}$ of buffer powder, $10 \mathrm{~mL}$ of water was added and after stirring, the clear slurry solution was obtained.

As it was stirred, it was slowly poured into $500 \mathrm{~mL}$ volume with water. Then, $10 \mathrm{~g}$ of Tween-20 was added to the solution and the $\mathrm{pH}$ of the buffer was adjusted between 7.2 - 7.8.

This buffer was stored at $4{ }^{\circ} \mathrm{C}$ when used at room temperature and when not in use.

\section{General extract buffer compounds}

$\begin{array}{cc}\text { Sodium sulfite (anhydrous) } & 0.65 \mathrm{~g} \\ \text { Polyvinylpyrrolidone (PVP) MW 24 - 40,000 } & 10.0 \mathrm{~g} \\ \text { Sodium azide } & 0.1 \mathrm{~g} \\ \text { Powdered egg (chicken) albumin, Grade II } & 1.0 \mathrm{~g}\end{array}$

3. Buffer ECM provision: To prepare $100 \mathrm{~mL}$ of ECM buffer, dissolve $0.4 \mathrm{~g}$ of lean milk in 100 $\mathrm{mL}$ of PBST wash buffer and stir for 30 minutes and adjust the $\mathrm{pH}$ of the buffer to 7.4.

This buffer was stored at $4{ }^{\circ} \mathrm{C}$ when used at room temperature and when not in use. This buffer requires 100 microliters for each well. The buffer was used for eight wells of $800 \mu$ l.

4. Preparation of PNP substrate buffer: To prepare $10 \mathrm{~mL}$ of PNP substrate buffer, $2 \mathrm{~mL}$ of PNP buffer $(\times 5)$ was dissolved in $8 \mathrm{ml}$ of distilled water. This buffer was provided when in use.

\section{PNP buffer compounds}

After dissolving the following substances in $800 \mathrm{~mL}$ of distilled water, the volume was brought to $1000 \mathrm{~mL}$.

$\begin{array}{cc}\text { Magnesium chloride hexahydrate } & 0.1 \mathrm{~g} \\ \text { Sodium azide } & 0.2 \mathrm{~g} \\ \text { Diethanolamine } & 97.0 \mathrm{ml} \\ \mathrm{pH} \text { (adjust pH to with hydrochloric acid) } & 9.8\end{array}$

5. Providing positive control: The bottle containing positive lyophilized control was dissolved in $2 \mathrm{~mL}$ of extraction buffer. Positive control was maintained at $-20{ }^{\circ} \mathrm{C}$ when used at room temperature and when not in use. $100 \mathrm{~mL}$ of this solution was added to the well.

6. Leaf or tuber extraction: Before extraction, each plate was numbered from 1 to 96 according to sample number. The ratio of leaf or tuber sample to buffer was $10: 1$ (g: $\mathrm{mL}$ ). $0.1 \mathrm{~g}$ of each leaf or tuber sample was extracted in $1 \mathrm{~mL}$ of public extraction buffer inside a Chinese mortar. 


\section{Procedure}

\section{Step One: Distributing the samples}

$100 \mu \mathrm{l}$ of leaf or tuber extract was added to each well. Instead of leaf or tuber extract, six wells of positive control solution with concentrations of $0,5,25,50,75$ and $100 \%$ were added to three wells of negative control and to three wells of buffer extraction.

100 wells were added to each well. Three wells were considered as empty wells (without material).

\section{Stage Two: Incubation}

After adding leaf or tuber extract, positive and negative controls and extraction buffer to the plate wells, they were placed in a box containing wet paper towels and kept at room temperature for 2 hours.

\section{Step Three: Preparation of enzyme conjugate}

$10 \mathrm{~min}$ before the end of the incubation phase, to prepare $10 \mathrm{~mL}$ of Enzyme conjugate, from bottle A (Detection antibody) and bottle B (Alk phos enzyme conjugate) (100: 1 dilution), each containing $100 \mathrm{~mL}$ of $10 \mathrm{~mL}$. EC ECM buffer was added.

\section{Step Four: Washing the plate}

After the end of the incubation phase, the plates were washed with PBST wash buffer seven times carefully without mixing the contents of the wells.

After filling the wells with 200 microliters of PBST wash buffer, wait about 5 minutes and then vacuum them and place the plate upside down on the paper towel to remove the wash buffer droplets. The wells should be without plant tissue.

\section{Step Five: Adding enzyme conjugate}

At this stage, $100 \mu \mathrm{l}$ of Enzyme conjugate was added to each well.

\section{Stage Six: Incubation}

At this point, the plates were kept in a box containing wet paper towels for $2 \mathrm{~h}$ at room temperature.

\section{Step 7: Preparation of PNP solution}

15 minutes before the end of the incubation phase, two PNP tablets weighing $5 \mathrm{mg}$ were added to the $10 \mathrm{~mL}$ PNP buffer, stored at room temperature, and dissolved in the dark.

\section{Step Eight: Plate wash}

After the end of the incubation phase, the plates were washed with PBST wash buffer eight times carefully without mixing the contents of the wells.

After filling the wells with the PBST wash buffer, quickly vacuum them and then place the plate upside down on the paper towel to remove the wash buffer droplets.

\section{Step 9: Adding PNP solution}

At this stage, $100 \mu \mathrm{l}$ of PNP solution was added to each well.

\section{Stage 10: Incubation}


At this point, the plates were kept in the dark in a box containing a wet paper towel for 60 minutes at room temperature. At this point the plates were protected from direct and intense light.

\section{Step 11: Evaluating the results}

1. Observation: Wells yellow in samples were infected with the virus.

2. Using ELISA: Remove any bubbles before reading plate with ELISA.

Potato virus was measured by BioTek ELISA according to the RIDAWin software at $405 \mathrm{~nm}$.

The formula $\mathrm{R}=\overline{\mathrm{x}}+3 \mathrm{SD}$ was used to determine contamination and non-contamination of samples (Salazar, 1996; Ahmadvand and Hassanabadi, 2009).

$\overline{\mathrm{X}}=$ Mean Absorption Rate of Negative Controls

$\mathrm{SD}=$ standard deviation of negative control absorbance values

If the amount of sample read from the ELISA machine was greater than the value of $\mathrm{R}$, it was taken as the sample infected with the virus.

\section{Results and discussion}

Analysis of variance showed that there was a significant difference between the studied areas and isolation interval at $1 \%$ probability level and 5\% probability level between years (Table 4).

Table 4. Mean squares of tuber yield at isolation intervals of three and two years in potato cultivar Agria with superalite seed class

\begin{tabular}{|c|c|c|}
\hline Sources of varation & degree of freedom & means of square \\
\hline Areas & 2 & 336.51 \\
\hline Year & 1 & *92.41 \\
\hline Regions $\times$ Year & 2 & $15.51^{\text {ns }}$ \\
\hline Error & 12 & 27.51 \\
\hline Isolation distance & 4 & ***65.28 \\
\hline Areas $\times$ Isolation distance & 8 & $4.34^{\mathrm{ns}}$ \\
\hline Year $\times$ isolation distance & 4 & $1.42^{\mathrm{ns}}$ \\
\hline Areas $\times$ years $\times$ isolation distance & 8 & $9.75^{\mathrm{ns}}$ \\
\hline Error & 48 & 18.53 \\
\hline Coefficient of variation & - & 10.31 \\
\hline
\end{tabular}

$*$ and ${ }^{* *}$ significant at 5 and $1 \%$ probability levels

Comparison of mean tuber yield in studied regions showed that Ardabil region had the highest value and was classified in group a. The lowest tuber yield was in the Nair region (Figure 1). Compared to other regions, Ardebil region had the most appropriate factors for altitude, total rainfall, minimum temperature, average daily temperature, absolute minimum temperature, frost days, sunny hours and air pressure for potato cultivation. Therefore, areas that are similar in character to the Ardabil region may be suggested for the production of potato mini-tubers.

The comparison of mean tuber yield at five isolation intervals showed no significant differences between 500, 400 and $300 \mathrm{~m}$ intervals and were in the a, ab and abc groups. The lowest tuber yield was in two distances of 200 and $100 \mathrm{~m}$ and was not significantly different (Figure 2). Yield of tuber differed between 500 and 100 about 4.5 t/ha. By reducing the isolation distance from $500 \mathrm{~m}$ to $100 \mathrm{~m}$ in potato seed production cultivar 
Agria with superalite seed class from host of viral vectors (edible Agria potato), tuber yield increased from $44.328 \mathrm{t} /$ ha to $39.828 \mathrm{t} /$ ha decreased (about $4.5 \mathrm{t} / \mathrm{ha}$ or $10.15 \%$ ).

Isolation distance is the minimum separation required between two or more varieties of the same species for the purpose of keeping seed pure. Transmission of viral viruses has decreased within $500 \mathrm{~m}$ between farms, but as isolation distance has decreased, transmission of viral viruses has increased.

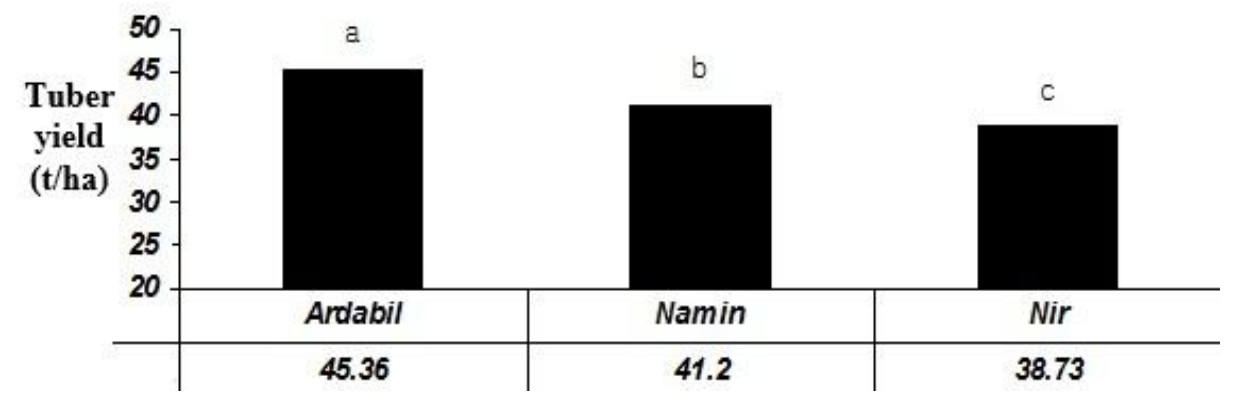

Figure1. Mean tuber yield in the three study areas

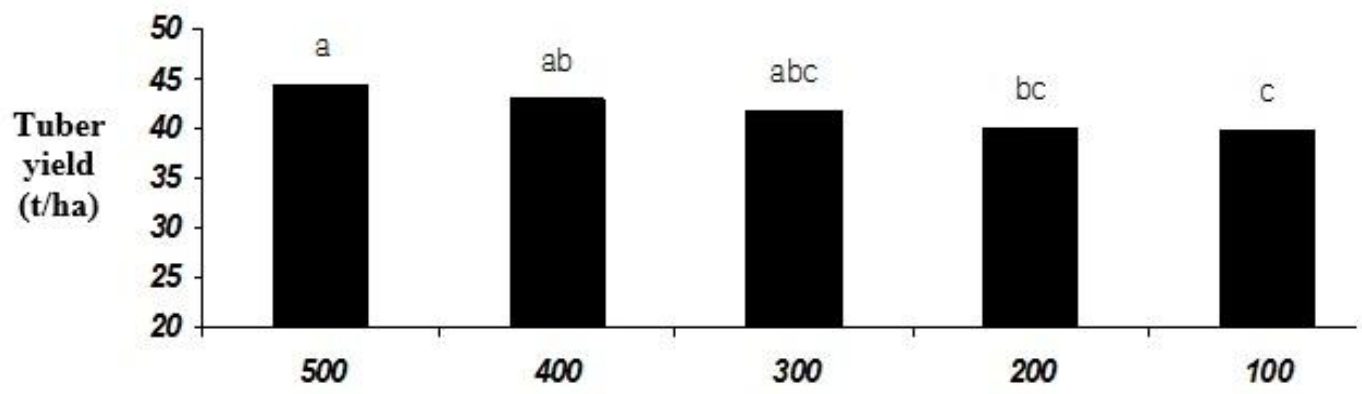

Figure 2. Mean tuber yield at the five isolates studied

The results of tuberculosis rhizoctonia showed that in all isolates and three study areas, about $5 \%$ of rhizoctonia was observed (Table 5). Ardebil region had the highest rate of infection $(6.8 \%)$ and Nair area had the lowest rate $(3.2 \%)$. In the three regions and 5 distances studied, the potato tubers were without vascular caries fungal disease and without bacterial diseases of the black leg and brown rot.

Table 5. Mean percentage of Rhizoctonia fungal disease in the isolation intervals studied in three regions

\begin{tabular}{ccccccc}
\hline Areas & $\mathbf{1 0 0}$ & $\mathbf{2 0 0}$ & $\mathbf{3 0 0}$ & $\mathbf{4 0 0}$ & $\mathbf{5 0 0}$ & Average \\
\hline Ardebil & 8 & 6 & 8 & 6 & 6 & 6.8 \\
Namin & 5 & 4 & 5 & 7 & 6 & 5.4 \\
Nair & 3 & 4 & 3 & 3 & 3 & 3.2 \\
Average & 5.33 & 4.67 & 5.33 & 5.33 & 5.00 & 5.13 \\
\hline
\end{tabular}

PVY virus was detected in leaf and tuber specimens prepared from isolation intervals at 100, 200 and 300 m intervals. In Ardabil region, PVY virus was 6\% in 100 meters, 4\% in 200 meters and 3\% in 300 meters. In Namin region, the amount of PVY virus was $5 \%$ at 100 meters, $200 \%$ and 300 meters at $3 \%$ and in the Neyir area at $4 \%$ at 100 meters, $2 \%$ at 200 
and 300 meters (Table 6). PVY virus was not observed in the three study areas at distances of 400 and $500 \mathrm{~m}$ from the host (Table 6). Potato viruses of PLRV, PVA, PVX, PVM, and PVS were not detected in field samples obtained from field samples.

Table 6. Mean PVY virus disease at the isolation intervals studied in three regions

\begin{tabular}{ccccccc}
\hline Areas & 100 meter & 200 meter & 300 meter & 400 meter & 500 meter & Average \\
\hline Ardebil & 6 & 4 & 3 & - & - & 4.30 \\
Namin & 5 & 3 & 3 & - & - & 3.70 \\
Nair & 4 & 2 & 2 & - & - & 2.67 \\
Average & 5 & 3 & 2.67 & - & - & 3.56 \\
\hline
\end{tabular}

Insects collected from the yellow pan installed in Agria potato seed production farm, $1.18 \%$ green peach aphid, $1.78 \%$ trips, $32.54 \%$ green zebra, $57.99 \%$ brown zebra, $18.1 \%$ of moths were potatoes and $5.33 \%$ were insects (Table 7). The tubers produced in three regions at the studied isolation intervals were free from contamination with potato moth.

Potato is a vegetatively propagated crop; hence the crop vigour and yield largely depends upon the quality of seed material obtained. Usually the farmers are in practice of purchasing smaller tubers from cold stores without bothering much about quality as it is cheaper. But if the seed tubers are disease affected then the yield is found to be very poor. The practice is very obvious because cost of seed itself becomes more than half of the total cost of cultivation and non availability of seed at sowing time compels the farmers to purchase the tubers from the nearest convenient place.

Table 7. Percentage of pests identified at the isolation intervals studied in the three zones

\begin{tabular}{ccc}
\hline Pests & Number & Percentage \\
\hline Myzus persicae & 2 & 1.18 \\
Trips spp & 3 & 1.78 \\
Empoasca faba (Harris) & 55 & 32.54 \\
Agallia spp & 98 & 57.99 \\
Phthorimaea operculella & 2 & 1.18 \\
Other insects & 9 & 5.33 \\
Total & 169 & 100 \\
\hline
\end{tabular}

\section{References}

Ahmadvand, R, Hassanabadi, H. (2009). Evaluation of Resistance of Potato Promising Clones to PVX, PVY and PVA in Greenhouse. Seed Plant Improv.J., 4(25):517-531.

Anonymous. (2005). Potato tissue culture minituber (PTMT) standard for certification. Shimla, India.

Beykzadeh N, Jafarpour B, Falahati Rastgar, M, Varasteh AAR. (2001). Investigation on Potato Virus X in North of Khorasan. J Agric Sci. 11(2): 7-21.

Bhutta, RA. (2008). Survey of tuber-borne diseases of potato in northern areas, Pakistan. Pakistan J. Phytopathol., 21:20-37. 
Bostan, H, Guclu, C, Oztuk, E, Ozdemir, I, Ilbagi, H. (2006). Influence of Aphids on the epidemiology of potato virus diseases (PVY, PVS and PLRV) in the high altitude areas of Turkey. Pakistan J. Biol. Sci., 9(4):759-765.

Buchen Osmond, C. (2002). ICTVdB: The Authorized Universal Virus Database. Biosphere 2 Center, Columbia University, Columbia.

De Boks, JDH. (1987). Viruses of potato and seed potato production. Wageningen, Netherlands. $259 \mathrm{pp}$.

Duan, G, Zhan, F, Du, Z, Ho, SYW, Gaoa, F. (2018). Europe was a hub for the global spread of potato virus $S$ in the 19th century. Virology., 525:200-204.

Haase, NU. (2008). The canon of potato science: 50. The nutritional value of potatoes. Potato Res., 50:415-417.

Hassanpanah, D. (2013). Evaluating Potential Production of Mid-Late Maturing Minituber of Potato Cultivars and Promising Clones under Aeroponic System. J. Crop Ecophysiol., 3(31):331346.

Khurana, S. (2004). Potato viruses and their management. Diseases of Fruits and Vegetables. 2:389-440.

Lung'aho, C, Lemaga, B, Nyongesa, M, Gildermacher, P, Kinyae, P, Demo, P, Kabira, J. (2007). Commercial seed potato production in eastern and central Africa. Kenya Agricul. Res. Institute, (KARI)., pp1-140.

Mattews, REF. (1991). Plant virology. Academi Press, Inc. San Diego, CA, USA. p 835.

Mondal, S, Wenninger, EJ, Hutchinson, PJS, Whitworth, JL, Shrestha, D, Eigenbrode, SD, BosquePérez, NA, Snyder, WE. (2017). Responses of Aphid Vectors of Potato leaf roll virus to Potato Varieties. Plant disease., 101(10):1812-1818.

Murphy, PA, Mckay, R. (1932). A Comparison of some European and American viruses disease in potato. Sci. Proceed. Royal Dublin Soc., 20:347-385.

Muthuraj, R. (2013). Pot seed certification. Division of Seed Technology, Central Potato Research Institute, Shimla. p 8.

Nasir, M, Zaidi, SSH, Batool, A, Hussain, M, Iqbal, B, Sajjad, M, Abbas, W, Javed, MM. (2012). ELISA-based detection of major potato viruses in tissue culture produced potato germplasm. Int.J. Agricult. Sci., 2(1):75-80.

Olubayo, F, Kibaru, A, Nderitu, J, Njeru, R, Kasina, M. (2010). Management of aphids and their vectored diseases on seed potatoes in Kenya using synthetic insecticides, mineral oil and plant extract. J. Innovat. Develop. Strat., 4(2):1-5.

Pazhouhandeh, M, Karvan, G, Razavi A. (2000). A review on potato genetic engineering researches yet. Genetic Engineering and Biosafety Journal. 6 (1) :175-188. 
Ragsdale, D, Radcliffe, E, diFonzo, CD. (2001). Epidemiology and field control of PVY and PLRV. Kluwar Academic Publishers, Dordrecht, the Netherlands.

Rolot, JL. (2005). Analyse des Facteurs Régulant la Dissémination du Virus Y de la Pomme de Terre (Pvy) en Vue de Stratégies de Lutte Raisonnées. Gembloux, Belgium: Faculté des Sciences agronomiques de Gembloux, PhD thesis.

Salazar, LF. (1996). Potato viruses and their control. CIP Peru. p 214.

Valkonen, JPT. (2007). Viruses: economical losses and biotechnological potential. In: Vreugdenhil D, ed. Potato Biology and Biotechnology. New York, NY, USA: Elsevier, p 619-41.

How to cite this article: Hossein Karbalaei Khiavi, Davoud Hassanpanah, Determine of Isolation Distances for Seed Potato Production in Ardabil Region. International Journal of Advanced Biological and Biomedical Research, 2020, 8(3), 225-235. Link: http://www.ijabbr.com/article 37331.html 